\title{
Dobras poli-harmônicas e estilos de dobramento em rochas carbonáticas da Mina de Salto de Pirapora, Votorantim, SP
}

\author{
Celso Dal Ré Carneiro \\ Instituto de Geociências, Universidade Estadual \\ de Campinas, Campinas, SP. \\ cedrec@ige unicamp.br \\ Ancilla Maria Almeida de Carvalho \\ Mestre pelo Programa de Pós-Graduação em \\ Geociências, Instituto de Geociências, Unicamp, \\ Campinas, SP. \\ ancillacarvalho@yahoo.com.br \\ Aline Ramos Bianchini \\ Geóloga pelo Instituto de Geociências, Unicamp, \\ Campinas, SP. \\ a_lineramos@yahoo.com.br
}

\begin{abstract}
RESUMO O presente artigo descreve exemplos de estruturas dobradas em rochas carbonáticas da mina de calcário de Salto de Pirapora, SP, pertencentes ao Grupo São Roque, de idade neoproterozoica. A exposição é excelente para ilustrar diferentes padrões morfológicos de dobras complexas e poli-harmônicas, e permite enfatizar diversos estilos estruturais típicos. O principal objetivo da pesquisa de campo foi identificar as classes de dobras existentes e comparar seus estilos. Aplicaram-se técnicas de tratamento digital de imagens, com classificação pelas isógonas de mergulho e ângulo de abertura. O artigo sintetiza conhecimentos e busca facilitar o ensino-aprendizagem de classificações morfológicas de dobramento, apoiado em sintese de conhecimentos, que abrange: sistemas de classificação, análise morfológica, contexto geológico regional e padrões de deformação em domínio dúctil. Os resultados revelam a importância da descrição detalhada das estruturas desde a etapa de campo, e acentuam a necessidade de se estudar a origem e mecanismo de formação das dobras poli-harmônicas.
\end{abstract}

PALAVRAS-CHAVE: Dobras, Geologia Estrutural; representações tridimensionais; Geologia; ensino-aprendizagem; tratamento digital de dados geológicos; estruturas em $3 D$.

\begin{abstract}
POLY-HARMONIC FOLDS AND FOLDING STYLES IN CARBONATIC ROCKS OF THE SALTO DE PIRAPORA MINE, VOTORANTIM, SP, BRAZIL. The paper is a detailed description of folded structures of the limestone mine of Salto de Pirapora, SP. The rocks belong to the Neoproterozoic São Roque Group, folded into a broad variety of styles, including typical poli-harmonic types; the individual sets reflect complex folding and refolding patterns. The survey has focused specific literature on classification of fold systems, fold styles, geometric characterization of fold types, regional geological context and ductile deformation patterns. To identify and compare fold types and styles of folding the first step was a detailed description and digital treatment of the major structural types, in parallel to the application of dip isogons and fold interlimb angles classification techniques. The study reveals the importance of understanding the origin and the formation mechanism of poly-harmonic folds.
\end{abstract}

KEYWORDS: Fold structures; Structural Geology; structural representations; Geology; teaching-learning; digital treatment of geological data; $3 D$ structures. 


\section{Introdução}

A mina de Salto de Pirapora está localizada no município de Votorantim, Estado de São Paulo, sendo operada pela Cia. de Cimento Votorantim para produção de cimento Portland (Fig. 1). A mina está implantada em espessa unidade de rochas carbonáticas metamórficas (Fig. 2) do Grupo São Roque. As frentes de lavra de calcários incluem exposições magníficas de quartzitos e calcários impuros (metamargas), sobrepostos e localmente intercalados com rochas cálcio-silicáticas. As camadas se apresentam intensamente dobradas, com estilos que incluem desde dobras abertas a sanfonadas, até isoclinais. $\mathrm{Na}$ área foram identificadas estruturas relacionadas a dobramento poli-harmônico. O conjunto, de origem tectônica, resulta de uma evolução geológica marcada por eventos magmáticos, metamórficos e deformacionais.

A área constitui exposição completa de dobras e padrões de dobramento do embasamento neoproterozoico paulista. Sucessivas vezes, alunos da disciplina de Geologia Estrutural, do curso de Geologia da Unicamp, visitaram a mina para observar dobras, foliações, falhas e juntas em rochas carbonáticas, além de aumentar seu conhecimento sobre estilos e padrões de dobramento.

\section{Objetivos}

Inicialmente, os estudos tiveram o objetivo de produzir um Atlas Digital da Mina de Salto de Pirapora, dada a grande variedade de dobras em rochas carbonáticas ali presentes. Classificaram-se exemplos de dobras abertas, sanfonadas e isoclinais, associadas a sistema de dobramento poli-harmônico de grande porte. O estudo bibliográfico focalizou o contexto geológico regional, com a finalidade de apoiar a elaboração de descrições detalhadas e o tratamento digital dos principais tipos de estruturas dobradas. A análise concentrou-se no reconhecimento dos tipos de dobras presentes na área da mina, buscando reunir um número pequeno, porém representativo, de exemplos mais típicos.

Com o acervo de estruturas descritas e analisadas, passou-se para a etapa de sistematização de dados de campo e formulação de proposta de classificação, com a finalidade de identificar os principais estilos e padrões de dobramento. O presente artigo pretende facilitar o ensino-aprendizagem de classificações morfológicas de dobramento e contribuir para o entendimento dos mecanismos de formação de dobras poli-harmônicas.

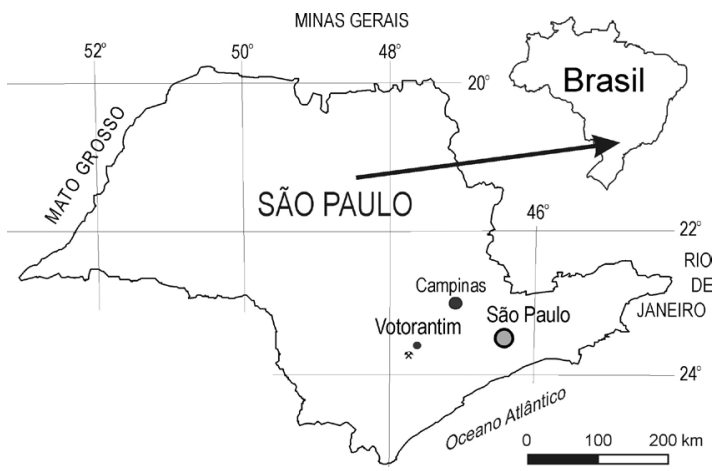

Figura 1. Localização mina de Salto de Pirapora em Votorantim, SP

\section{Materiais e métodos}

Para investigar os padrões deformacionais associados a dobramento na área, realizaram-se diversos trabalhos de campo, quando foi recolhida rica documentação fotográfica. As imagens digitais exemplificam as estruturas dobradas da mina de Salto de Pirapora, catalogadas e armazenadas em banco de dados.

A pesquisa bibliográfica sobre a geologia do embasamento cristalino paulista recuperou trabalhos publicados em áreas de afloramento do Grupo São Roque, assim como estudos que abordam a distribuição das rochas carbonáticas em São Paulo. Em paralelo, realizou-se revisão dos sistemas de classificação de dobras e dobramentos, para subsidiar comparações entre as estruturas observadas em campo e as estruturas catalogadas. A fundamentação teórica sobre classificação de dobras apoiou a interpretação das estruturas dobradas. Para elaborar as representações utilizaram-se recursos de desenho em ambiente $\mathrm{CAD}$, tendo como overlay as fotografias feitas em campo.

\section{Desenvolvimento de Atlas Digital}

Para desenvolver o Atlas Digital das estruturas dobradas da Mina de Salto de Pirapora, foi necessário construir uma base de dados das estruturas documentadas em imagens de campo desde o ano de 2006. Catalogaram-se e armazenaram-se as fotografias coletadas, contendo exemplos de estilos de dobras e padrões de dobramento, com cerca de 40 imagens. Quinze delas fazem parte de um Atlas Digital, ainda inédito. O critério de escolha envolveu tanto a qualidade e resolução da imagem como a existência de diferentes morfologias de dobras. A partir das imagens em formato JPEG foram desenvolvidas representações e interpretações das estruturas dobradas existentes na área de 


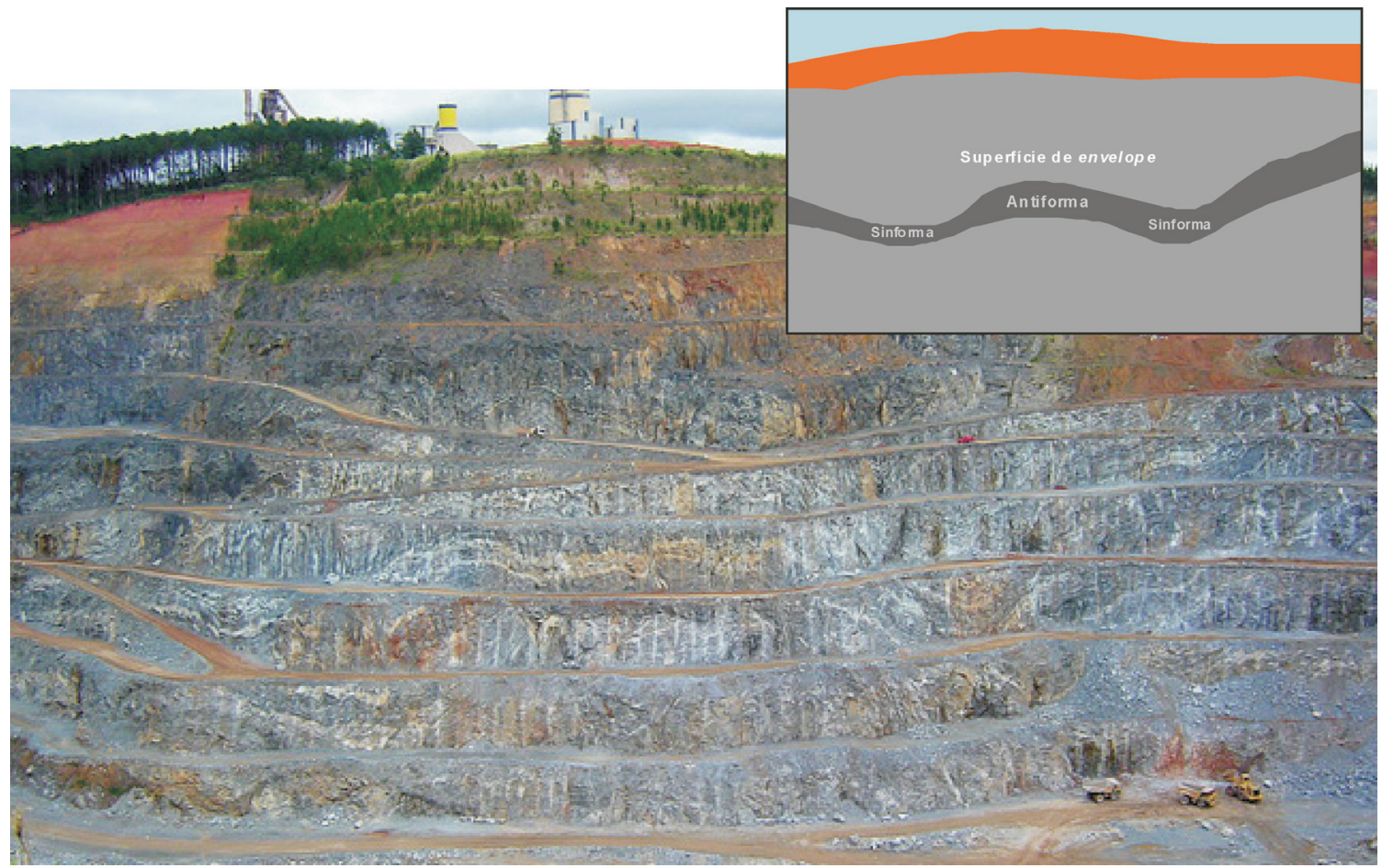

Figura 2. Visão geral da face norte da frente de lavra

estudo. Para isso foi utilizado o ambiente CAD, que permite digitalização de contornos estruturais e utilização das imagens como planos de fundo, com precisão e boa fidelidade. A digitalização procurou representar as camadas quartzosas e rochas carbonáticas dobradas e feições associadas, como foliações e lineações.

A digitalização envolveu a representação de características morfológicas utilizadas para classificação de dobras. Os atributos e principais características representáveis são: ângulo de abertura da dobra, superfície axial, amplitude, comprimento da dobra e isógonas de mergulho. Após digitalizadas as dobras, os arquivos DWG foram transformados em arquivos de imagem no formato TIFF ou JPEG. Para cada estilo de dobra foi criada uma imagem contendo a foto como plano de fundo e uma imagem contendo somente o traçado das feições estruturais e suas características morfológicas.

\section{Contexto geológico regional}

A área de estudo, compreendida por rochas do Grupo São Roque, configura uma faixa de orientação aproximadamente E-W, localizada entre os blocos Jundiaí e Embu. A área de exposição do Grupo São Roque está controlada por grandes falhamentos transcorrentes, sendo limitada a norte pelos Falhamentos de Jundiuvira-Extrema (Carneiro 2001) e
Itu, a sul pelo Falhamento Taxaquara e a oeste pela borda da Bacia do Paraná.

\section{Breve Histórico dos Estudos de Geologia do Sul- Sudoeste Paulista}

As rochas epimetamórficas do Complexo Cristalino, aflorantes no Estado de São Paulo, foram denominadas por Moraes Rego (1930) como Série São Roque. Trabalhos posteriores utilizaram a mesma denominação e o conteúdo geológico-estrutural foi abordado por Hennies et al. (1967). Hasui et al. (1969) reconheceram três entidades tectônicas contrastantes em termos de padrões litológicos e estruturais: os Blocos Cotia, São Roque e Jundiaí. O Bloco São Roque é composto de epimetamorfitos de fácies xistos verdes - filitos sericíticos e grafitosos com quartzitos dominantes - e subordinadamente calcários e dolomitos metamórficos, metabasitos, itabiritos e metaconglomerados oligomíticos. Rochas carbonáticas constituem corpos lenticulares numerosos na região de Votorantim e Boturuna, com granulação fina, compondo-se de carbonatos, quartzo e ocasionalmente de sericita e matéria carbonosa, e mostrando-se bastante fraturadas e silicificadas. Os epimetamorfitos encontram-se penetrados por batólitos e stocks graníticos, localmente com auréolas de metamorfismo de contato.

Coutinho (1972) discute a continuidade geo- 
gráfica dos Grupos São Roque e Açungui, tendo reunido as rochas de idade pré-cambriana superior na mesma unidade. $\mathrm{O}$ autor apresenta descrição petrográfica e mineralógica detalhada das rochas do Grupo São Roque denominando-as de metassedimentos de origem clástica associados a anfibolitos e rochas granitóides intrusivas. Caracterizou os seguintes litotipos: (i) metaconglomerados: camada com espessura de 500 metros, de composição constante com predomínio de seixos graníticos sobre os de quartzitos e outros, em matriz de natureza grauváquica, nos quais acha-se presente forte deformação; (ii) metarenitos impuros (meta-arcósios e metagrauvacas): composição variável rica em quartzo e feldspatos; (iii) meta-arenitos mais puros (quartzitos): constituído de mais de $80 \%$ de quartzo recristalizado; (iv) filitos: formados por sericita, quartzo, turmalina e subordinadamente feldspato detritíco; (v) micaxistos, resultantes da elevação do grau metamórfico de metassedimentos mais finos; predomínio de quartzo, muscovita, biotita e em menor quantidade sillimanita, almandina, estaurolita e turmalina; (vi) rochas cálcio-silicáticas: compostas por quartzo, feldspato, anfibólio, diopsídio e epidoto, geralmente de granulação fina; (vii) rochas granitóides: adamellitos e granodioritos formando maciços e corpos menores, composição granodiorítica e textura ígnea hipidiomórfica; (viii) corpos anfibolitícos: distribuídos em lentes e faixas constituídas por anfibólios e plagioclásios; (ix) epidositos e clorita xistos ricos em albita, epidoto e/ou clorita recristalizados sob condições de fácies xistos verdes.

Apesar de a proposição de Coutinho (1972) ser reforçada por Hasui (1973), em estudos das folhas São Roque e Pilar do Sul, Hasui (1975a) definira o Grupo São Roque como unidade distinta do Grupo Açungui ao reconhecer a disposição das unidades em blocos justapostos e com diferentes histórias deformacionais. $\mathrm{Na}$ abordagem de Hasui (1975b), grandes falhas dividiram a área em compartimentos; formaram-se os Blocos Itapuranga, Pirapitingui, Moreiras e Juqueri, que compõem o Conjunto São Roque, enquanto os Blocos Cotia e Juquitiba compõem o Conjunto Paranapiacaba.

Hasui et al. (1976) propuseram a divisão estratigráfica do Grupo São Roque em duas unidades: a inferior denominada de Formação Boturuna composta por filitos sericíticos e intercalações de quartzito na parte basal e rochas carbonáticas no topo - e uma unidade superior denominada Formação Piragibu - composta por filitos rítimicos ou alternância de filito/quartzito. Destacaram ainda que a tectônica transcorrente foi posterior ao metamorfismo regional controlando a intrusão de corpos graníticos. No mesmo ano Hasui e Sadowski (1976) separaram o Grupo Açungui do contexto do Grupo São Roque, subdividindo o primeiro em Complexos Pilar e Embu. O Complexo Pilar seria formado por um conjunto de filitos e xistos e o Complexo Embu por migmatitos e gnaisses migmatizados. Esta proposição foi adotada no Mapa Geológico do estado de São Paulo (Bistrichi et al. 1981) e respectiva nota explicativa (Hasui et al. 1981).

Coutinho et al. (1982) estudaram uma sequência vulcano-sedimentar que consideraram integrante da base do Grupo São Roque, admitindo que os pacotes formados poderiam ser compostos essencialmente por rochas vulcânicas básicas, tufos básicos, margas, sedimentos argilosos e silicáticos com baixo grau de metamorfismo regional (fácies xistos verdes), resultando em anfibolitos maciços e bandados, rochas calciosilicatadas, filitos (sericita xistos), quartzitos, e ainda uma intrusão granítica que teria imposto características de hornfels a várias rochas. Estes autores descrevem dez diferentes unidades litológicas pré-cambrianas, abrangendo os litotipos anteriormente citados.

O embasamento do Grupo São Roque foi descrito por Carneiro (1983) como unidade mais antiga composta por gnaisses biotíticos e migmatitos (Almeida et al. 1981), e uma segunda unidade, composta por rochas miloníticas, milonito-gnaisses e blastomilonitos dobrados. A composição da última unidade seria dada por bandas claras quartzo-feldspáticas com bandas mais escuras de composição biotítica a moscovitíca.

Em estudo detalhado de aproximadamente 2.000 afloramentos do Grupo São Roque na Faixa entre o Pico do Jaraguá e a Serra dos Cristais, Carneiro (1983) identificou alguns conjuntos litológicos: metassedimentos detríticos com predomínio de metapsamitos impuros; metasedimentos detritícos com predomínio de metapsamitos puros; metassedimentos químicos e químicos detríticos, como mármores, calcários e dolomitos; anfibolitos, metabasíticos e rochas metavulcânicas hipoabissais. Essas unidades litoestratigráficas foram afetadas por três fases de dobramento e submetidas a metamorfismo regional. O estudo revelou que em geral a xistosidade e a clivagem ardosiana ocorrem paralelas à estratificação reliquiar.

Carneiro (1983) e Carneiro et al. $(1984,1985)$ 


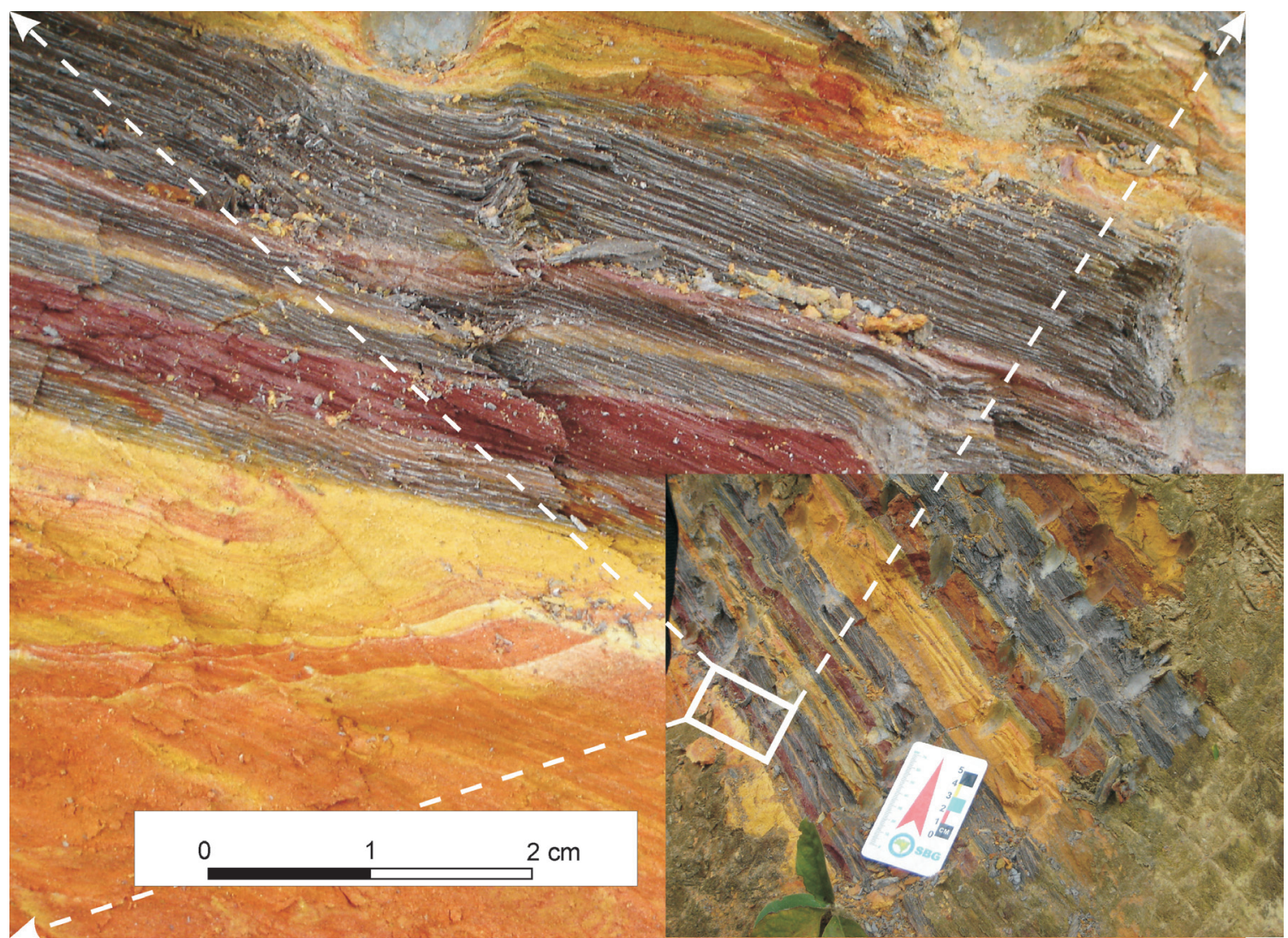

Figura 3. Aspecto mesoscópico de bandamento diferenciado, de escala microscópica, associado a planos da clivagem de crenulação $S_{2}$. A alternância de planos claros e escuros, que caracteriza a feição, são mais visíveis nas bandas escuras do filito. Pirapora do Bom Jesus, SP

descrevem a presença de típico bandamento diferenciado, de dimensões microscópicas a submicroscópicas, vinculados ao padrão de clivagem de crenulação. $\mathrm{O}$ bandamento diferenciado é a mais importante feição diagnóstica das rochas metapelíticas do Grupo São Roque (Fig. 3). Na última fase de deformação teria havido regime transtensivo inicial associado à colocação de granitos brasilianos, sucedidos por um regime transcorrente/transpressivo marcado por foliação milonítica sob uma tectônica dúctil-rúptil e um regime transpressivo final.

Juliani et al. (1986) revisaram a organização do Grupo São Roque, e propuseram o termo Grupo Serra do Itaberaba para aquela que seria a sua porção basal. Tal proposição baseia-se em diferenças de eventos tectônicos, ambiente geológico, grau metamórfico, idade geocronológica e metalogênese. Os autores sugerem que a denominação Grupo São Roque deveria ser aplicada somente para metamorfitos originados a partir de sedimentos depositados em águas rasas com predomínio de pelitos rítmicos e intercalações de psamitos, conglomerados, arcóseos, grauvacas e rochas carbonáticas.
Na região entre Salto de Pirapora e Votorantim, Silva (2004) reconheceu quatro associações de litofácies. As associações referem-se a ambientes de sedimentação que variam de marinho profundo passando a marinho raso e lagunar. As associações de litofácies foram descritas pelo autor da seguinte maneira, da base para o topo:

- Associação de litofácies A, siliciclástica basal: compreende metassiltitos laminados, metaritmitos, metarenitos feldspáticos a arcosianos, alguns tipos quartzosos, filitos sericíticos e grafitosos, e eventuais níveis de metargilitos maciços. A associação foi dividida em cinco litofácies: metassiltitos laminados, metarenitos maciços a levemente estratificados, metarritmitos, filitos bandados a laminados e metargilitos maciços, compreendendo um contexto deposicional de águas profundas associadas a uma sucessão turbidítica.

- Associação de litofácies B, siliciclástica intermediária: compreende três litofácies: metassiltitos laminados e maciços, metargilitos maciços, metarenitos quartzosos. As litofácies eviden- 
ciam condições de deposição de plataforma rasa de caráter progradante.

- Associação de litofácies $C$, unidade clastoquímica transicional: esta associação inclui litofácies como metassiltitos maciços e laminados, metamargas laminadas a bandadas; metadolomitos, metacalcilutitos e metacalcarenitos dolomíticos bandados; metacalcários (metacalcilutitos predominantemente laminados e bandados) e por fim biotita-clorita filitos bandados. As condições de deposição são referidas como plataforma rasa até ambiente de sedimentação determinado por maré (intramaré passando a intermaré).

- Associação de litofácies $D$, unidade carbonática impura superior: compreende metadolomitos e metacalcilutitos, metacalcários maciços, e porção restrita de quartzo-filitos e filitos laminados. Esta associação localiza-se próxima às instalações da fábrica de cimento Votoran I. O contexto deposicional corresponde provavelmente a planície de maré (intermaré a supramaré).

As associações foram correlacionadas, de maneira informal, pelo autor (Silva 2004), às formações propostas por Bergmann (1988), que propôs identificar três formações do Grupo São Roque, subdivididas em membros de diferentes características geológicas. O posicionamento estratigráfico das formações foi redefinido por Hackspacher et al. (1993).

Godoy et al. (1996) descreveram as unidades do Grupo São Roque, com base na divisão proposta por Bergmann (1988). As unidades foram descritas como:

- Formação Estrada dos Romeiros: porção basal do Grupo São Roque, constituída de metarritmitos com intercalações de metarenitos feldspáticos e metapelitos.

- Formação Voturuna: constituída por metassiltitos em contato basal gradativo com as rochas da unidade inferior, sobrepostos por quartzitos puros a micáceos, também feldspáticos, em contato abrupto.

- Formação Pirapora (topo): reune metabásicas e metacalcários, em contato abrupto com a unidade subjacente.

\section{A Formação Pirapora}

A Formação Pirapora, foco do presente trabalho, havia sido individualizada da Formação Boturuna (Hasui et al. 1976). Godoy et al. (1996) também a individualizam na subdivisão tripartite que propõem. É composta por rochas metassedimentares, clásticas e químicas. As rochas clásticas seriam representadas por intercalações pelítico-psamíticas, com predomínio de tipos rítmicos sobre tipos meta-argilosos, sericita filito e sericita grafita filito, que gradam para níveis ricos em carbonatos. A presença de metapelitos indica ambiente de plataforma distal e espessa lâmina d'água.

As rochas químicas compreenderiam todas as rochas carbonáticas, ou seja: metacalcários calcíticos, cálcio-filitos e rochas cálcio-silicáticas. Entre os metacalcários estão presentes tipos oolíticos, pisolíticos e oncolíticos, que resultam de precipitação inorgânica e bioquímica, em ambientes de intermarés ou proximais com águas quentes e agitadas. O principal litotipo dessa unidade é o metacalcário calcítico de granulação fina, que apresenta estruturas foliadas, bandadas, e corpos com geometria lenticular. A associação mineralógica encontrada corresponde a carbonatos de cálcio e magnésio, quartzo, sericita e grafita, sendo frequentes as intercalações de metacalcário dolomítico com metacalcário calcítico. Os calcifilitos bandados apresentam estrutura foliada a bandada, intercalada com termos mais calcíticos. As rochas cálcio-silicáticas, por sua vez, encontram-se nas minas de metacalcário com estrutura bandada ou maciça, com textura lepidogranoblástica muito fina, dobradas (Fig. 4) e comumente cortadas por veios

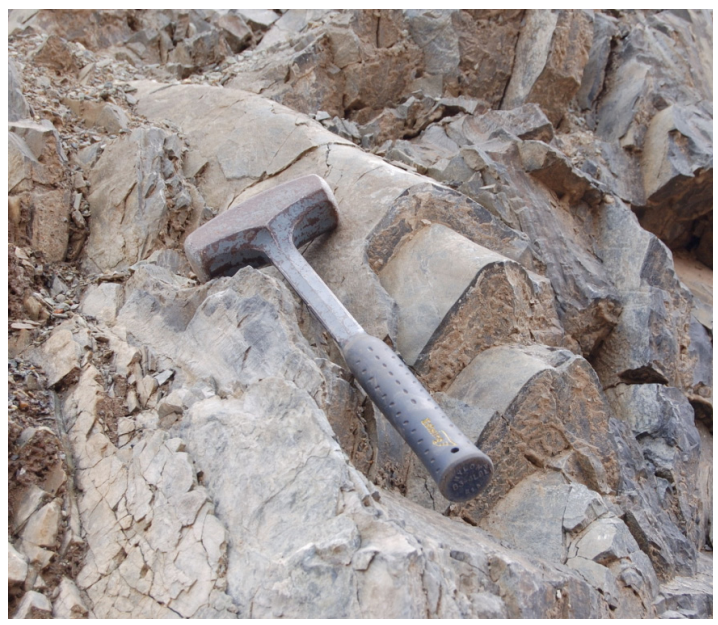

Figura 4. Dobra de ápice espessado, de escala mesoscópica, em rochas cálcio-silicáticas bandadas da Mina de Salto de Pirapora, Votorantim, SP 
de quartzo e carbonatos.

Silva (2004) estabeleceu critérios detalhados de reconhecimento das litofácies da Associação de litofácies C e da Associação de litofácies D; em função de sua importância para o presente estudo, são a seguir transcritas.

- Metadolomitos, metacalcilutitos e metacalcarenitos dolomíticos bandados: foi verificada na Mina de Salto, consistindo de um arranjo plano-paralelo no qual predominam camadas de coloração cinza claro (carbonatos e quartzo) intercaladas a níveis mais claros (opacos como constituintes pricipais);

- Metacalcários (metacalcilutitos predominantemente laminados e bandados): ocorrem sob forma de corpos alongados e/ou lenticulares, situados a leste e nordeste de Salto de Pirapora. Correspondem a tipos bandados caracterizados por faixas claras constituídos de carbonatos e quartzo.

- Metadolomitos e metacalcilutitos dolomíticos bandados, laminados e maciços: refere-se a ocorrências da Mina Baltar e do Pastinho, onde os corpos são alongados e/ou lenticulares com espessura aparente estimada de 200-400m. Predominam os tipos laminados e bandados, caracterizados por níveis alternados de cor cinza médio a escuro, além de metacalcários;

- Metacalcários maciços: compreendem rochas escuras (pretas) na sua maioria e composição calcítica, aflorantes nas Minas Baltar, da Placa e Pastinho.

\section{0 problema das idades absolutas}

Considerando os metaconglomerados do Grupo São Roque como possivelmente basais, Tassinari et al. (1985 apud Juliani et al. 1986) obtiveram idades de metamorfismo $(\mathrm{Rb} / \mathrm{Sr})$ de aproximadamente $800 \mathrm{Ma}$ e seixos de granito-gnaisse com 1.200 Ma indicando que a idade de sedimentação seria posterior a este valor. As rochas aflorantes na região entre Salto de Pirapora e Votorantim indicaram idades de 2,44 Ga e de 1,86 Ga para as rochas-fonte, em metarritmitos e filitos do Grupo São Roque, resultados de datações $\mathrm{Sm} / \mathrm{Nd}$ (Dantas et al. 2000). Datações U-Pb em zircões provenientes de metandesitos indicam idades em torno de $1,4 \mathrm{Ga}$ para o início da deposição de pelitos e vulcanismo do Grupo Serra do Itaberaba (Juliani et al. 2000), tido como anterior ao Grupo São Roque.

Hackspacher et al. $(1999,2000)$ efetuaram datações U-Pb em rochas metavulcânicas, indicando que a deposição do Grupo São Roque teria ocorrido entre 0,628 e 0,607 Ga. Henrique-Pinto et al. (2012) analisaram seixos e a matriz do metaconglomerado do Morro Doce (Fm. Boturuna), buscando elucidar a proveniência das rochas. As idades de seixos graníticos analisados revelam vínculo com fontes magmáticas arqueanas a paleoproterozoicas, enquanto a matriz arcosiana pode ser correlacionada a uma ou mais fontes máficas mais jovens.

Datações $\mathrm{K} / \mathrm{Ar}$ efetuadas nas rochas máficas do Grupo Serra do Itaberaba forneceram $1.690 \pm$ $157 \mathrm{Ma}$ (Juliani et al. 1986 apud Juliani et al. 2000), sugerindo que a deposição e o metamorfismo da sequência vulcano-sedimentar antecederia a deposição do Grupo São Roque. Valores de $1.790 \pm 14$ Ma, obtidos por Van Schmus et al. (1986 apud Juliani et al. 2000) a partir de zircões datados pelo método $\mathrm{U} / \mathrm{Pb}$ são interpretados como de cristalização magmática do metarriodacito do Morro do Polvilho, intercalado com a parte basal do Grupo São Roque e datado por Van Schmus et al. (1986 apud Juliani et al. 2000). A rocha foi reinterpretada por Juliani et al. (1997 apud Juliani et al. 2000) como meta-arcósio intercalado com metaconglomerado na porção basal do Grupo São Roque. As rochas metamórficas do Grupo São Roque devem representar uma sequência de bacia de retroarco; a deposição ter-se-ia iniciado em ambiente de mar raso (Hackspacher et al. 1999, Dantas et al. 1999 apud Juliani et al. 2000).

\section{Evolução metamórfica e estrutural}

Três fases de deformação associadas à orogênese brasiliana foram identificadas por Carneiro (1983) e Bistrichi (1984), que podem ser identificadas por meio de inúmeras relações de superposição de estruturas. Os episódios deram origem a dobras de flanco invertido e dobras recumbentes. A foliação sub-horizontal mais antiga está associada a provável transporte para SE (Hackspacher et al. 1991 apud Hackspacher et al. 1993). Foram identificados dois eventos metamórficos no Grupo São Roque, representados por rochas das fácies xistos verdes a anfibolito. A terceira fase de deformação desenvolveu dobras normais portadoras de clivagem de crenulação subvertical associada a metamorfismo na fácies xistos verdes a anfibolito regional (Carneiro 1983), sucedidas por metamorfismo de contato 
nas vizinhanças dos maciços Sorocaba e São Roque.

Para Godoy et al. (1996) o metamorfismo imposto aos metassedimentos do Grupo São Roque atingiu condições de fácies xistos verdes, aparecendo em sua fase inicial juntamente com as fases deformacionais $\mathrm{D}_{\mathrm{n}+1} / \mathrm{D}_{\mathrm{n}+2}$, alcançando o ápice metamórfico durante a fase $\mathrm{D}_{\mathrm{n}+2}$, e a fase $\mathrm{D}_{\mathrm{n}+3}$ de caráter retrometamórfico. Segundo Silva (1997 apud Silva 2004) todo o conjunto de metassedimentos do Grupo São Roque na área entre Salto de Pirapora e Votorantim teria sido afetado por três fases progressivas de deformação. A primeira fase $\left(\mathrm{D}_{\mathrm{n}}\right)$ possui natureza dúctil, devida a uma cinemática de baixo ângulo, responsável por dobras locais a semi-regionais que deformam o acamamento sedimentar $\left(\mathrm{S}_{0}\right)$, e desenvolvem foliação tectono-metamórfica $\left(\mathrm{S}_{\mathrm{n}}\right)$. As fases de deformação $\mathrm{D}_{\mathrm{n}+1}$ e $\mathrm{D}_{\mathrm{n}+2}$ referem-se a uma cinemática de alto ângulo, em zona de transição dúctil-rúptil. A fase $\mathrm{D}_{\mathrm{n}+1}$ seria caracterizada pelo desenvolvimento de dobras de estilos variados sobre a foliação anterior $\left(\mathrm{S}_{\mathrm{n}}\right)$, como desenvolvimento local de foliação plano-axial $\left(\mathrm{S}_{\mathrm{n}+1}\right)$, que evolui para foliação milonítica $\left(\mathrm{S}_{\mathrm{m}}\right)$ associada a desenvolvimento de zonas de cisalhamento transcorrente de caráter dúctil-rúptil. Já a fase de deformação $\mathrm{D}_{\mathrm{n}+2}$ representaria os efeitos transpressivos tardios ligados ao cisalhamento, caracterizado pela formação de dobras normais, suaves, abertas.

A foliação plano-axial $\left(\mathrm{S}_{\mathrm{n}+1}\right)$, descrita por Silva (2004), corresponde, provavelmente, à clivagem de crenulação $S_{2}$ associada a típico bandamento diferenciado em filitos, conforme descrito por Carneiro (1983), e Carneiro et al. (1985) (Fig. 3).

\section{Dobras: morfologia e classificação}

Dobras são feições curvilíneas resultantes de deformação dúctil, sem perda da continuidade das feições planares ou lineares envolvidas. A deformação ocorre sob diversas condições de esforços, pressão hidrostática, pressão de poros internos e temperaturas, resultando na mudança de forma e/ou volume de um conjunto rochoso. A deformação também resulta de reorientações dos esforços ao longo do tempo.

Vários controles determinam a geometria final de uma dobra. Os controles primários são: (a) a natureza e composição das camadas dobradas e (b) mudanças de comportamento reológico de cada tipo de rocha envolvida, ocasionadas por diferenças de temperatura e pressão durante a formação das dobras e (c) desenvolvimento de novos grãos minerais durante a deformação. Outros fatores são: (d) propriedades mecânicas das interfaces entre camadas, (e) contrastes de viscosidade das camadas dobradas, (f) espessura de cada camada constituinte do pacote de rocha e (g) presença de diferentes camadas de rochas agrupadas em uma mesma unidade. Interferem ainda no processo de dobramento (h) natureza do limite das unidades de rochas submetidas a dobramento e (i) escalas e dimensões do pacote de multicamadas que foram dobradas (Ramsay e Huber 1987).

As escalas de dobramento podem ser reunidas em três categorias:

1. Macroscópica (regional): dobras dessa categoria possuem dimensões que geralmente ultrapassam a capacidade de observação direta, sendo observáveis apenas em mapas, fotos e imagens, aéreas ou orbitais;

2. Mesoscópica: inclui dimensões que oscilam desde grandes afloramentos, cortes e exposições no terreno, até dimensões da ordem das amostras de mão;

3. Microscópica: as dimensões envolvidas são pequenas, exigindo o uso de aparatos especiais, como lupas, microscópios e outros instrumentos para observação.

\section{Classificação geométrica de dobras}

Para auxiliar a caracterização morfológica dos principais tipos de dobras, foram reunidas em tabelas (Tabs. 1 a 12) as principais definições e critérios de classificação de dobras, junto com esquemas. Definições, conceitos e termos usuais em Geologia Estrutural são facilmente encontrados na literatura especializada e portanto não são aqui reproduzidos.

Existem diversas classificações de estruturas dobradas, baseadas em diferentes critérios de descrição, muitas vezes combinados entre si. Toda classificação atende a uma diferente necessidade prática, sendo muito útil distinguir pelo menos três categorias descritivas principais:

1. Descrição de dobras isoladas;

2. Descrição de sistemas dobrados;

3. Descrição de dobras segundo a forma em perfil.

\section{Dobras isoladas}

Para descrever e classificar dobras isoladas, utilizam-se três componentes:

a. Forma da superfície dobrada em três dimensões (Tab. 1), o que permite distinguir primariamente as dobras cilíndricas daquelas 
não-cilíndricas (Van Der Pluijm e Marshak

2004);

Idade relativa das feições dobradas, critério que separa as dobras de polaridade normal (facing) daquelas de polaridade invertida. Sob esse critério, é possível distinguir os anticlinais e sinclinais dos sinclinais antiformais e anticlinais sinformais, a partir das seguintes categorias (Tabs. 2 e 3);

- Sinforma: concavidade para cima;

- Antiforma: concavidade para baixo;

- Sinclinal: concavidade e rochas mais jovens para cima;

- Anticlinal: convexidade e rochas mais jovens para cima.

b. Orientação espacial da dobra, utilizando-se os elementos plano axial e eixo de dobra (Tabs. 4 e 5).

\section{Sistemas dobrados}

$\mathrm{Na}$ descrição de sistemas dobrados, são de grande importância as seguintes feições: superfície envoltória (Tab. 6), superfície mediana, linha de inflexão e superfície axial, com base nas quais definem-se o comprimento de onda e amplitude dos sistemas dobrados, além de uma série de outras relações. Os sistemas dobrados podem ser divididos em conjuntos de dobras simétricas ou assimétricas, sendo estas últimas separadas pela forma em perfil, segundo as categorias M, S e Z. Dimensões mais amplas de dobramento em sistemas dobrados podem ser reveladas pela presença de feições, de escala regional, conhecidas como anticlinório e sinclinório.

Ao se descrever e classificar a forma das dobras em perfil, não é necessário levar em conta a orientação espacial da dobra, uma vez que o perfil da dobra é sempre perpendicular à linha de charneira. Três componentes são essenciais nessa classificação: (a) o ângulo interflancos (Tab. 7); (b) a relação entre as dimensões da zona de charneira e dos flancos adjacentes (Tabs. 8 e 9), e (c) as variações de espessuras das camadas dobradas (Tab. 10). Dentre estas, tem grande utilidade prática a classificação de dobras baseada no critério das isógonas de mergulho, que são linhas ortogonais às tangentes de pontos de mesmo mergulho nos perfis.

As isógonas de mergulho definem a existência dobras de ápices espessados, concêntricos ou adelgaçados, nas seguintes categorias: isógonas convergentes (Classes 1A, 1B e 1C), isógonas paralelas (Classe 2) e isógonas divergentes (Classe $3)$. As classes de dobras resultantes desse critério de classificação são as categorias de dobras de ápices adelgaçados (Classe 1A), dobras concêntricas, paralelas ou isópacas (Classe 1B) e dobras de ápices espessados (Classe 1C, Classe 2 e Classe 3). As dobras da Classe 2 são também chamadas similares, em virtude de exibirem um perfil cujo padrão é repetido sucessivas vezes ao longo das várias dobras.

Outra possibilidade de classificação refere-se ao estilo de multicamadas dobradas, na qual o estilo é definido em termos de harmonia do dobramento e a geometria da superfície axial. Em perfil, um dobramento harmônico seria contínuo e exibiria multicamadas dobradas terminando em ambas as direções ao longo do traço axial, para muitos múltiplos de meios-comprimentos de onda. Já no caso de dobra desarmônica, esta terminará ao longo do traço axial dentro de poucos pares de meios comprimentos de onda, tendendo a possuir amplitudes e comprimentos de ondas diferentes no perfil (Fig. 6). Dobras desarmônicas possuem divergências ou mesmo convergências muito pronunciadas de isógonas de mergulho, diferentemente das dobras harmônicas, que tendem a ser mais próximas do padrão similar.

Em resumo, dobras que exibem um aspecto aproximadamente constante ao longo de todo o perfil do pacote dobrado (Tab. 11) são chamadas dobras harmônicas, enquanto aquelas não-persistentes em uma determinada escala de observação são denominadas desarmônicas (Hobbs et al. 1976).

Pelo fato de as multicamadas dobradas terminarem ao longo do traço axial, o mergulho das isógonas deveria formar contornos próximos entre duas charneiras adjacentes (Twiss e Moores 1992). Ao longo do traço da superfície axial de dobras harmônicas, à medida que aumenta a amplitude das dobras e esta alcança o máximo, para em seguida decrescer, o mergulho da isógona pode convergir e depois divergir, resultando em uma alternância de padrões como por exemplo 1B (ou 1C) e 3 .

Seguindo o raciocínio de Twiss e Moores (1992) em multicamadas dobradas todos os padrões de isógonas de mergulho podem ocorrer. Não devem, no entanto, ser ignoradas as diferenças intrínsecas das camadas como, por exemplo, o contraste de competência que, por sua vez permite estabelecer importante diferenciação entre tipos de dobras, classificadas segundo mecanismos clássicos prováveis (Tab. 12). 
Tabela 1. Classificação baseada na forma da linha de charneira (modif. Loczy e Ladeira 1976)

Definição
a linha de
charneira é
retilínea

Tabela 2. Classificação de dobras isoladas (Hobbs et al.1976)

\begin{tabular}{l|l}
\hline \multicolumn{1}{c|}{ Definição } & Esquema \\
\hline $\begin{array}{l}\text { Antiforma: dobra com flancos } \\
\text { convergindo para cima }\end{array}$ & \\
\hline $\begin{array}{l}\text { Sinforma: dobra com flancos } \\
\text { convergindo para baixo }\end{array}$
\end{tabular}

Tabela 3. Classificação baseada na idade relativa das camadas (Hobbs et al.1976)

\begin{tabular}{c|c}
\hline Definição & Esquema \\
\hline $\begin{array}{c}\text { Anticlinal: dobras } \\
\text { com estratos mais } \\
\text { velhos no núcleo da } \\
\text { dobra }\end{array}$ \\
\hline $\begin{array}{c}\text { Sinclinal: dobras com } \\
\text { estratos mais novos } \\
\text { no núcleo da dobra }\end{array}$ \\
\hline
\end{tabular}

Tabela 4. Classificação baseada no caimento do eixo (modif. Arthaud 1998)

Eixo horizontal Esquema

Tabela 5. Classificação baseada na atitude do plano axial (modif. Arthaud 1998).

Definição
Normal: Plano axial ver-
tical
Inclinada: Plano axial incli-
nado
Recumbente: Plano axial
horizontal
Recumbente: mergulho de
30-0
Invertida: mergulho de
Normal:


Tabela 6. Termos usuais na classificação de sistemas dobrados (modif. Hobbs et al. (1976).

\begin{tabular}{|c|c|c|}
\hline Nome & Definição & Esquema \\
\hline Dobras parasíticas & $\begin{array}{l}\text { São aquelas de tamanhos menores, } \\
\text { que ocorrem em flancos ou zonas de } \\
\text { charneira de dobras maiores }\end{array}$ & \\
\hline Superficie envoltória & $\begin{array}{l}\text { Superfície tangencial às charneiras de } \\
\text { algumas ou a todas as dobras de uma } \\
\text { dada superfície }\end{array}$ & \\
\hline
\end{tabular}

Tabela 7. Classificação baseada no ângulo de abertura da dobra (Segundo Fleuty 1964 apud Ramsay 1967)

\begin{tabular}{c|c}
\hline Definição & Esboço \\
\hline Suave: abertura de $180-120^{\circ}$ & \\
\hline Aberta: abertura de $120-70^{\circ}$ & \\
\hline Fechada: abertura de $70-30^{\circ}$ & \\
\hline Apertada ou cerrada: abertura de $30-0^{\circ}$ & \\
\hline Isoclinal: abertura de $0^{\circ}$ & $180^{\circ}$
\end{tabular}

Tabela 8. Classificação de tipos especiais de dobras conforme o perfil (Hobbs et al. 1976) (modif. dos autores citados)

Dink: dobras com flancos planares e com charneiras
Kingulares

Dobras em chevron: consiste nos flancos de uma kink possuir iguais comprimentos

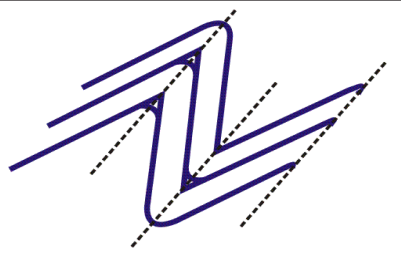

Dobra em caixa: são estruturas que definem três
lados de um retângulo

Dobras intrafoliais: dobras com charneiras apertadas
em rochas não obviamente dobradas. Estão geral-
mente inclusas em planos de foliação não-dobrada


Tabela 9. Classificação de dobras com idêntico ângulo de abertura a partir da relação entre os comprimentos das zonas de charneira e dos flancos da dobra (Ramsay 1967)

\begin{tabular}{ccc}
\hline Nome & Definição \\
Dobras arredondadas & $\begin{array}{c}\text { Dobras com charneiras amplas e flancos propor- } \\
\text { cionalmente muito pequenos }\end{array}$ \\
$\begin{array}{c}\text { Dobras sub-arredondadas ou } \\
\text { sub-angulares }\end{array}$ & $\begin{array}{c}\text { Dobras com charneiras e flancos de dimensões } \\
\text { aproximadamente iguais }\end{array}$ \\
$\begin{array}{c}\text { Dobras em chevron, em zigue- } \\
\text {-zague ou em acordeão }\end{array}$ & $\begin{array}{c}\text { Dobras com charneiras de dimensões extrema- } \\
\text { mente pequenas quando comparadas com os } \\
\text { comprimentos muito maiores dos flancos }\end{array}$
\end{tabular}

Tabela 10. Classificação baseada em isógonas de mergulho (Ramsay 1967, Ragan 1973)

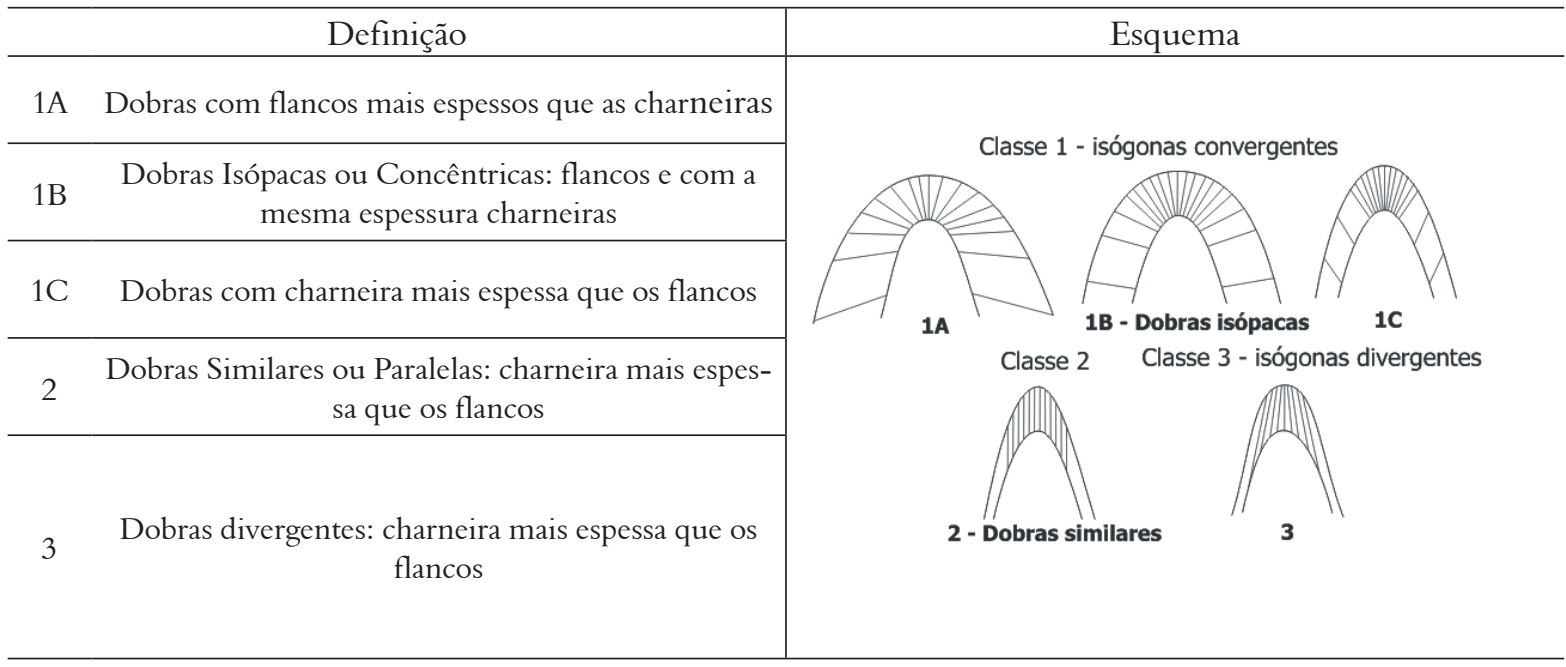

\section{Geologia de Salto de Pirapora}

A lente calcária da Mina Salto de Pirapora possui direção N50E a N60E com mergulhos variando de $40^{\circ}$ a $60^{\circ}$ para NW, estando a SE em contato direto por falha com granitos. Esse nível é sobreposto por um pacote carbonático que varia de calcários impuros a rochas cálcio-silicatadas (Nakamura 1995). Os calcários são calcíticos, de coloração cinza médio a escuro e granulação fina-média predominante, chegando a grossa e sacaróide próximo ao contato com o granito. Estão entrecortados por vênulas centimétricas de calcita branca com algum quartzo associado, sem orientação preferencial. Epidotos, piroxênios e sulfetos são acessórios comuns. A fluorita é encontrada em zonas de fraturamento e falhamento e em uma faixa, larga de até 25 metros, no contato com o granito, com intercalações frequentes e rítmicas de hornfels metassomatizado. O pacote carbonático sobreposto faz contato gradacional com os calcários, variando de calcários impuros silicosos até rocha cálcio-silicatada. 
Tabela 11. Classificação de sistemas dobrados em perfil (Hobbs et al. 1976)

Definição
$\begin{gathered}\text { Dobras harmônicas: dobras cujo aspecto é } \\ \text { constante em todo o perfil do pacote dobrado }\end{gathered}$
$\begin{gathered}\text { Dobras desarmônicas: aspecto não é persistente } \\ \text { em determinada escala de observação }\end{gathered}$

Os calcários impuros são descritos como metarritmitos e metamargas (Nakamura 1995) e gradam para termos mais puros à medida que se aproximam dos calcários. São rochas fortemente bandadas, nas quais o bandamento é dado por faixas intercaladas de espessura variável de calcários magnesianos a dolomíticos, quartzitos a calcários silicosos contendo diopsídio e epidoto, além de veios de quatrzo. Sobreposta aos calcários impuros, observa-se no topo, com espessura pouco conhecida, uma rocha cálcio-silicatada que varia a calcário impuro extremamente silicoso na qual os teores médios de $\mathrm{CaO}$ estão abaixo de 30\%. Sua ocorrência diminui no rumo NE até desaparecer graças à erosão diferencial proporcionada pelo soerguimento do pacote carbonático devido à intrusão granítica (Nakamura 1995). Fenômeno idêntico ocorre com os calcários impuros, que também passam gradacionalmente para rocha cálcio-silicatada graças a incremento na quantidade de $\mathrm{SiO}_{2}$, associado a veios de quartzo e

Tabela 12. Classificação de mecanismos de dobramento, pelos modelos clássicos de formação de dobras (Hobbs et al. 1976)

\begin{tabular}{|c|c|c|c|}
\hline Nome & Definição & Esquema & \\
\hline $\begin{array}{c}\text { Dobras geradas } \\
\text { por flexão }\end{array}$ & $\begin{array}{l}\text { Dobram uma camada com super- } \\
\text { fície interna considerada neutra. } \\
\text { São dobras paralelas ou concên- } \\
\text { tricas (classe } 1 \mathrm{~B})\end{array}$ & & injer \\
\hline
\end{tabular}

Figura modificada de Arthaud (1998)

Dobras geradas por cisalhamento flexural
Envolvem cisalhamento nas superfícies paralelas como nas camadas dobradas; também se formam dobras concêntricas ou paralelas (classe 1B)

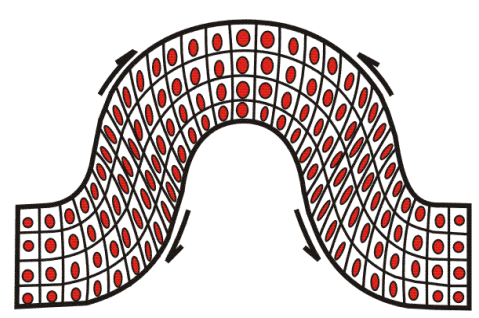

Figura modificada de Arthaud (1998) Dobras forma-
das por desli-
zamento
Envolvem cisalhamento nos espaços próximos a planos oblíquos às camadas dobradas. Formam-se dobras similares (classe 2)

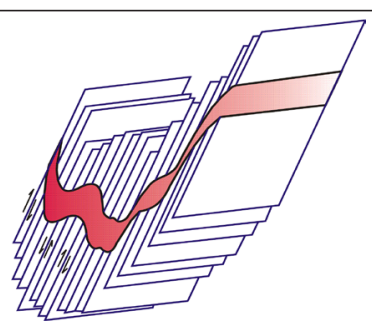

Figura modificada de Hobbs et al. (1976) 


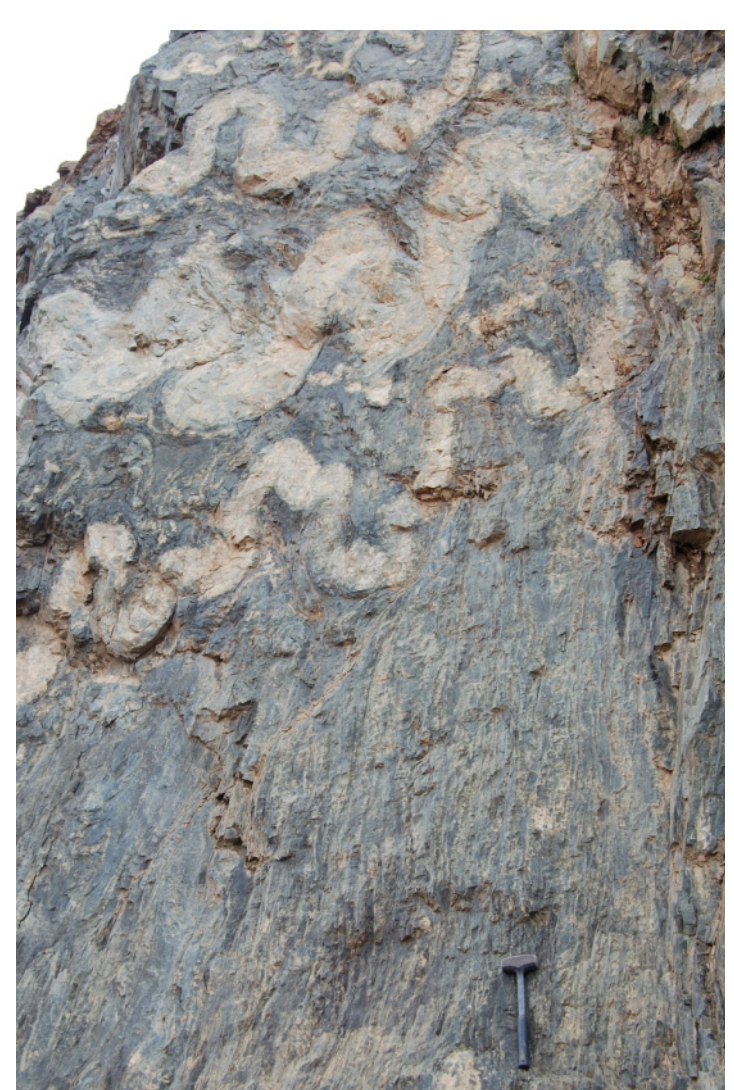

Figura 5. Dobras mesoscópicas em padrão poliharmônico, com ápices concêntricos até espessados

A. Dobras cerradas com charneiras arredondadas

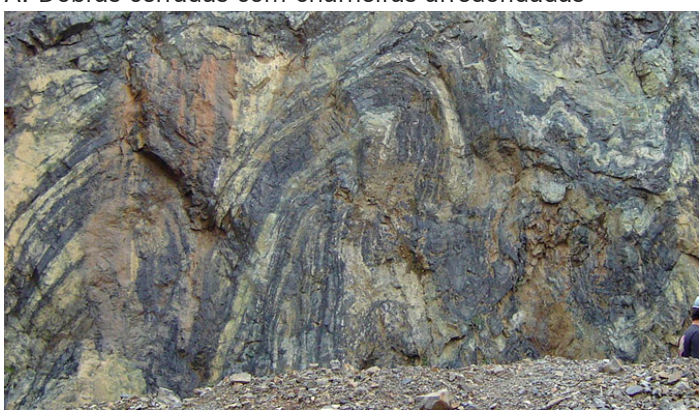

B. Classificação segundo isógonas de mergulho

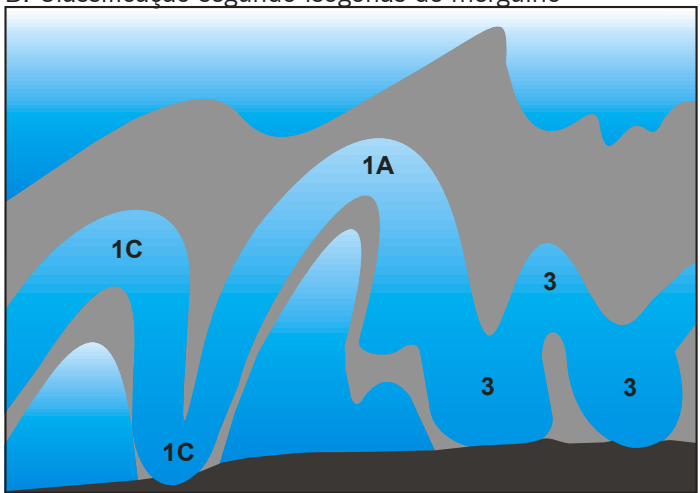

Figura 6. Classificação de dobras da Mina de Salto de Pirapora, parte I minerais silicáticos de magnésio e ferro. São rochas verdes, maciças e criptocristalinas.

O contato dos calcários com os granitos é representado por falha de empurrão ou reversa contendo mineralização de fluorita. Os falhamentos associados ao empurrão têm atitudes dominantes N50-60W subvertical e N05-10W subvertical. Na mina os falhamentos seriam observados sob a forma de grandes escorregamentos nos leitos de calcários impuros e sulcos profundos com alteração de rocha no maciço granítico. Em furos de sondagem, o efeito desses falhamentos se reflete em mantos profundos de alteração sem recuperação de rocha e/ou intenso fraturamento com preenchimento nas fraturas por material argilo-arenoso.

Os calcários acham-se muitas vezes cortados por brechas calcíticas e fluoríticas cujos teores em $\mathrm{CaF}_{2}$ variam de 5 a $60 \%$. As brechas que apresentam maior teor de $\mathrm{CaF}_{2}$ são aquelas que se encontram no contato com os granitos sendo este a principal falha mineralizada. $\mathrm{Na}$ faixa de contato do granito com calcários observa-se hornfels, com espessuras pouco significativas, que varia de poucos centímetros até três metros, com inclusões de fluorita verde a roxo.

\section{Estruturas locais}

O conjunto de rochas carbonáticas da Mina de Salto de Pirapora está sistematicamente dobrado, mas os horizontes mais notáveis e de interesse para estudo de padrões de dobramento encontram-se no contexto das metamargas ou rochas cálcio-silicatadas (Figs. 4 a 12). A interpretação realizada em fotografias de campo possibilitou identificar dobras geralmente fechadas a isoclinais, desarmônicas, na grande maioria de ápice espessado e arredondado, que variam de métricas a centimétricas (Fig. 5). A foto da figura $6 \mathrm{~A}$ permite ter visão abrangente da mina. A estrutura de grande porte foi interpretada na figura $6 \mathrm{~B}$ como uma superfície envoltória de dimensões métricas (Bianchini 2007), podendo ser classificada no intervalo de suave a aberta. Apesar da boa resolução digital da imagem, é difícil distinguir dobras menores, devido ao tamanho da zona exposta. As fotografias que fazem parte do Atlas Digital referem-se a zonas localizadas, ou pormenores, desta frente de lavra. As intercalações entre rochas carbonáticas e cálcio-silicatadas são facilmente delimitáveis acompanhando-se as diferentes tonalidades de cinza, que correspondem a diferentes teores de calcita e sílica das rochas carbonáticas intercaladas. 
Dobras ptigmáticas foram observadas em rochas cálcio-silicatadas (Fig. 6C), evidenciando diferenças de comportamento reológico das rochas durante a deformação. As dobras da figura 5, referidas como padrão de dobramento poli-harmônico também podem ser descritas como dobras ptigmáticas, que são um caso particular de dobras desarmônicas. Nas figuras 8 e 9 distinguiram-se dobras das classes 2 e 3 (Ramsay 1967); as diferentes dobras apresentadas em uma mesma camada e com grande proximidade entre elas refletem possíveis contrastes de viscosidade, durante o dobramento dos materiais presentes no perfil. $\mathrm{O}$ mesmo se aplica à figura $8 \mathrm{~B}$, na qual foram identificadas dobras da classe 3 .

\section{Atlas de dobras da Mina de Salto de Pirapora}

As figuras 10 e 11 constituem pequena amostra do acervo de imagens estruturais e respectivas interpretações que se pretende reunir, futuramente, em um atlas digital das estruturas encontradas na mina.

\section{Dobras Harmônicas}

A Figura 10 apresenta dobras harmônicas sanfonadas com ápices espessados e arredondados em porções de rochas carbonáticas (tons de cinza mais escuro) e cálcio-silicáticas (tons de cinza mais claro). As dobras são assimétricas e apresentam plano axial inclinado. Percebe-se a presença de foliação plano-axial bem marcada e associada a dissolução por pressão, evidenciada pela presença de pequenos intervalos planares de cor branca, paralelos à superfície axial da dobra e que cortam os regularmente os níveis carbonáticos mais escuros. Os ângulos de abertura são entre $30^{\circ} \mathrm{e} 70^{\circ}$ na maioria dos casos, caracterizando assim dobras fechadas, contudo percebe-se a presença de uma dobra isoclinal (estrutura "pinçada") na porção central da imagem.

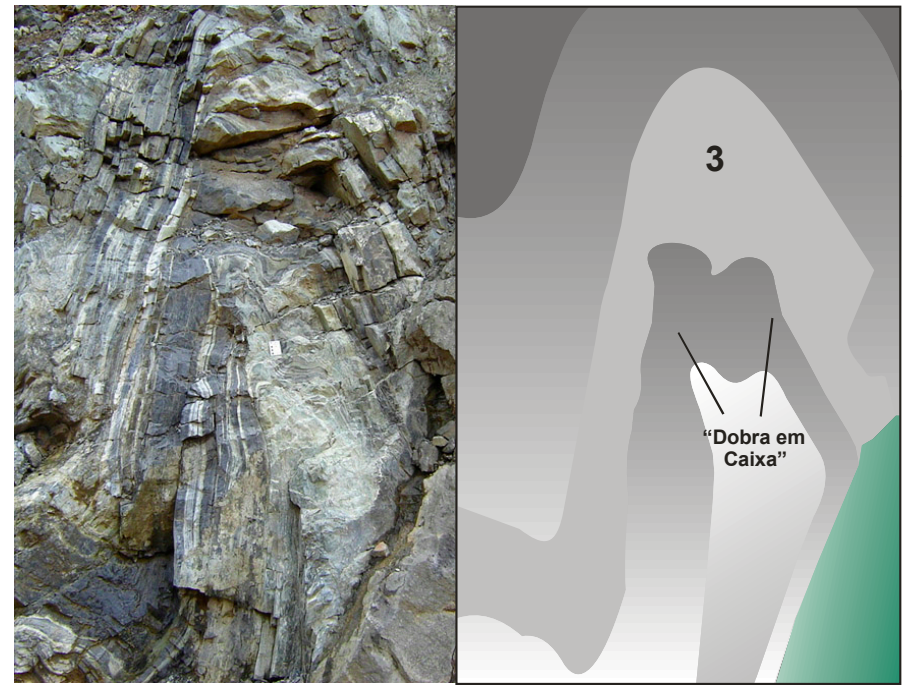

A. Dobra cerrada desarmônica de ápice espessado
B. Classificação segundo isógonas de mergulho
Figura 7. Classificação de dobras da Mina de Salto de Pirapora, parte II

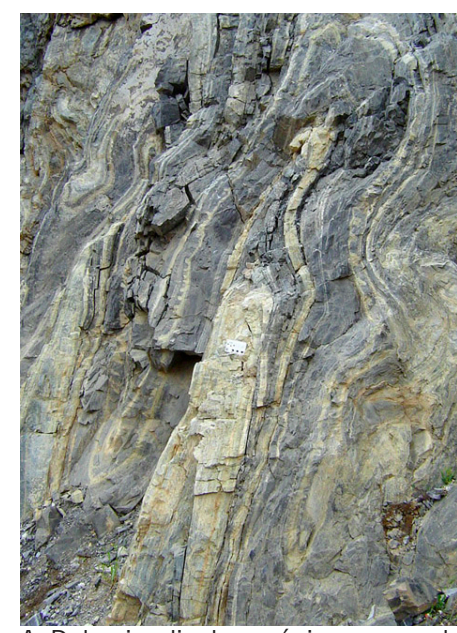

A. Dobra isoclinal com ápice espessado e evidências de redobramento

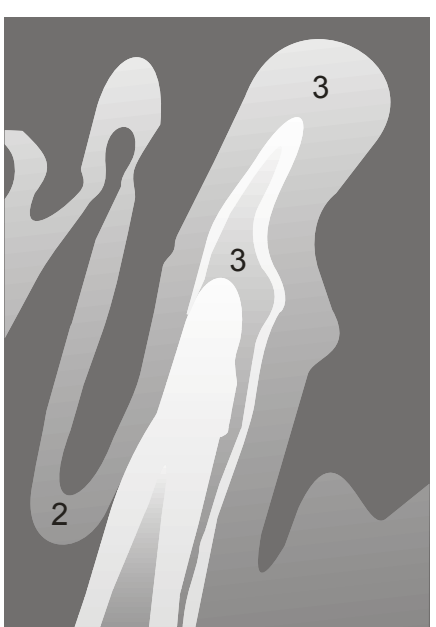

B. Classificação segundo isógonas de mergulho

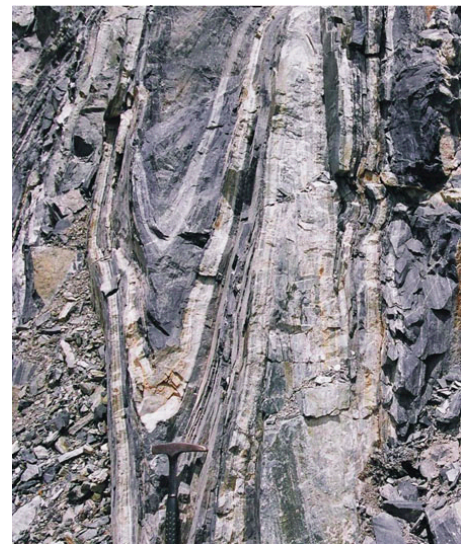

C. Dobra isoclinal com ápice espessado

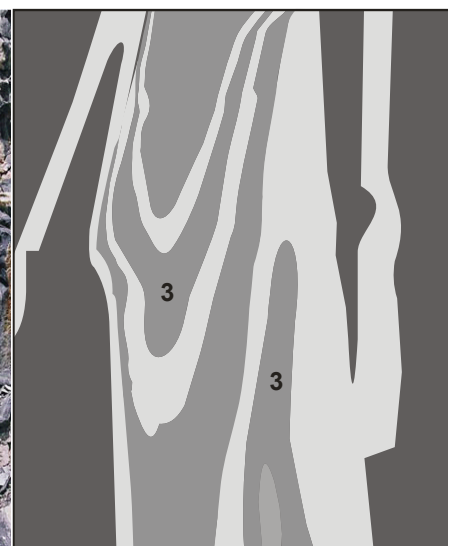

D. Classificação segundo isógonas de mergulho
Figura 8. Classificação de dobras da Mina de Salto de Pirapora, parte III 


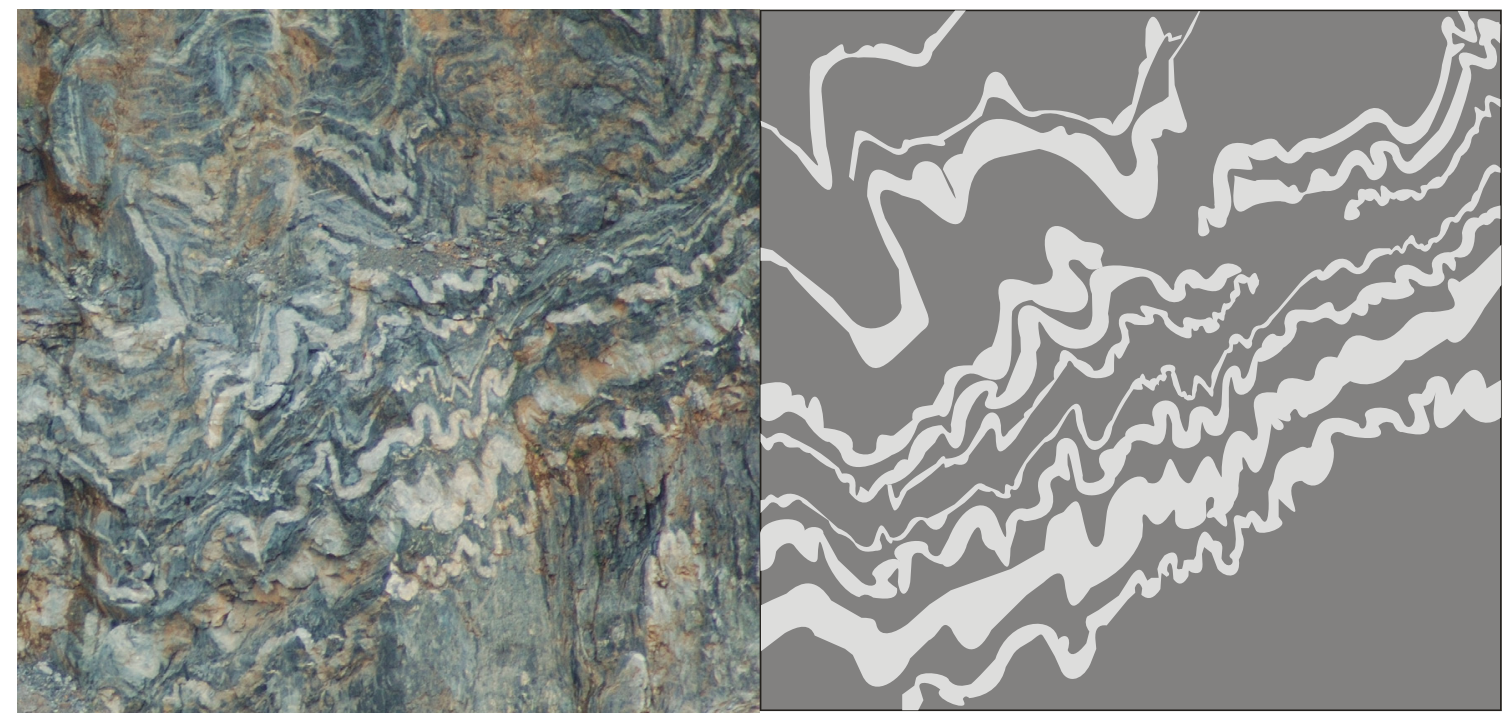

B. Esquema das multicamadas dobradas

A. Dobras desarmônicas arredondadas com variados comprimentos de onda e amplitudes

Figura 9. Classificação de dobras da Mina de Salto de Pirapora, parte IV

Segundo a classificação de isógonas de mergulho, as dobras pertencem às categorias de dobras similares (Classe 2) e dobras convergentes (Classe 1C).

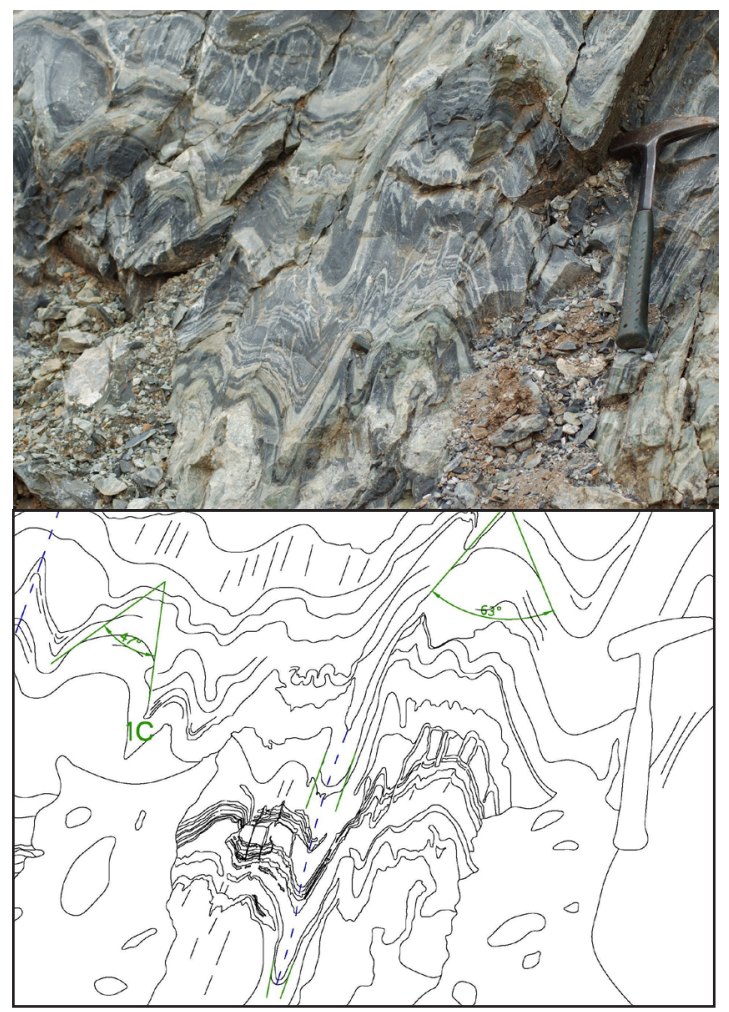

Figura 10. Classificação de formas dobradas, parte V. A. Dobras portadoras de clivagem plano-axial em rochas carbonáticas (cinza escuro) e cálcio-silicáticas (cinza claro); B. Interpretação de foliações dobradas e foliação pano-axial

\section{Dobra Isoclinal}

A Figura 11 exibe uma dobra isoclinal em porção de rocha cálcio-silicática (tom mais claro), juntamente com dobras cerradas em outras porções. A dobra isoclinal pode ser classificada como convergente da Classe 1C, com pequenas zonas pertencentes à Classe 3 , assim como as dobras presentes na porção esquerda da imagem.

O plano axial é curvilíneo e as dobras podem ser classificadas como harmônicas. A porção de rocha dobrada logo acima da dobra isoclinal sugere a existência de redobramento. A orientação do segundo
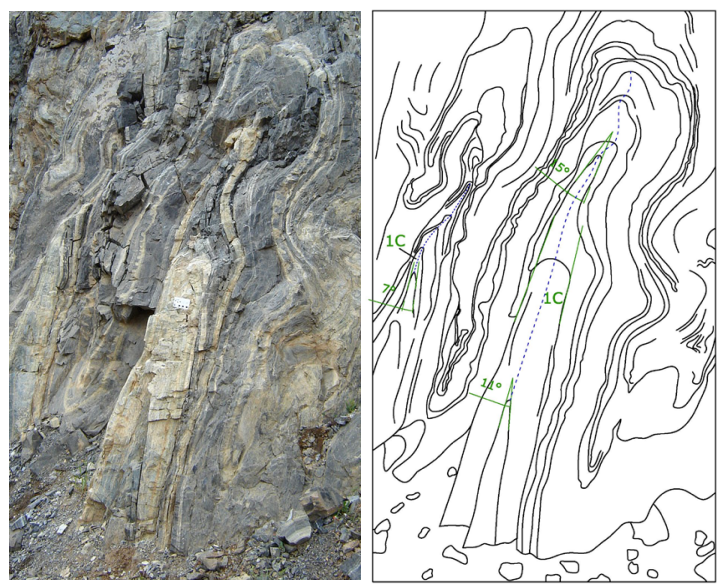

Figura 11. Classificação de formas dobradas, parte VI. A. Dobras isoclinais em rochas carbonáticas (cinza escuro) e cálcio-silicáticas (cinza claro); B. Interpretação de foliações dobradas e foliação plano-axial 
dobramento é aproximadamente ortogonal ao primeiro evento, que por sua vez é evidenciado por dobras com ângulo de abertura suave.

\section{Interpretação dos resultados}

As ilustrações e o pequeno Atlas que acompanha o presente artigo contêm imagens dos principais estilos de dobras encontrados na Mina de Salto de Pirapora, e ilustram até mesmo feições características de interferência de dobramentos sucessivos (Figs. 11 e 12). Espera-se que possam ilustrar atividades práticas sobre o tema e que ajudem os interessados em aprofundar-se no difícil campo de estudo dos padrões de dobramento e redobramento regional.

O processo de produção do atlas envolveu a representação das estruturas dobradas e a descrição pormenorizada das principais características morfológicas. Foram realizadas também interpretações por meio de softwares de ambiente CAD, de modo a auxliar a caracterização morfológica das feições. $\mathrm{O}$ avanço das escavações destruiu algumas das feições descritas, de tal sorte que o artigo pôde preservar registros de feições como, dentre tantas outras, a bela estrutura tridimensional da figura 4 .

A maior parte das dobras interpretadas na área da mina pertence às classes $1 \mathrm{C}$ e 3 da classificação de Ramsay (1967). A presença de clivagens disjuntivas em posição plano-axial das dobras estudadas permite correlacioná-las às dobras descritas por Santoro (1986), ou ainda às descritas por Carneiro (1983), que foram associadas a uma segunda fase de dobramento do Grupo São Roque, que desenvolveu dobras cerradas a fechadas com ápices espessados e grande variação de atitudes dos elementos estruturais, devido a dobramentos posteriores.

As figuras 6 a 11 sintetizam feições muito comuns na mina, que podem ser encontradas em outros domínios de rochas cálcio-silicatadas da região. O pacote estudado exibe complexo perfil de multicamadas dobradas cujo arranjo resultou de um padrão de dobramento desarmônico, associado a contraste de competência entre camadas. A recomposição da história estrutural é tarefa complexa, devido ao redobramento (Fig. 12).

\section{Considerações Finais}

Observa-se na Mina de Salto de Pirapora a repetição de perfis de multicamadas nos quais foram identificados padrões de dobramento desarmônico. A tectônica que afetou as rochas do Grupo

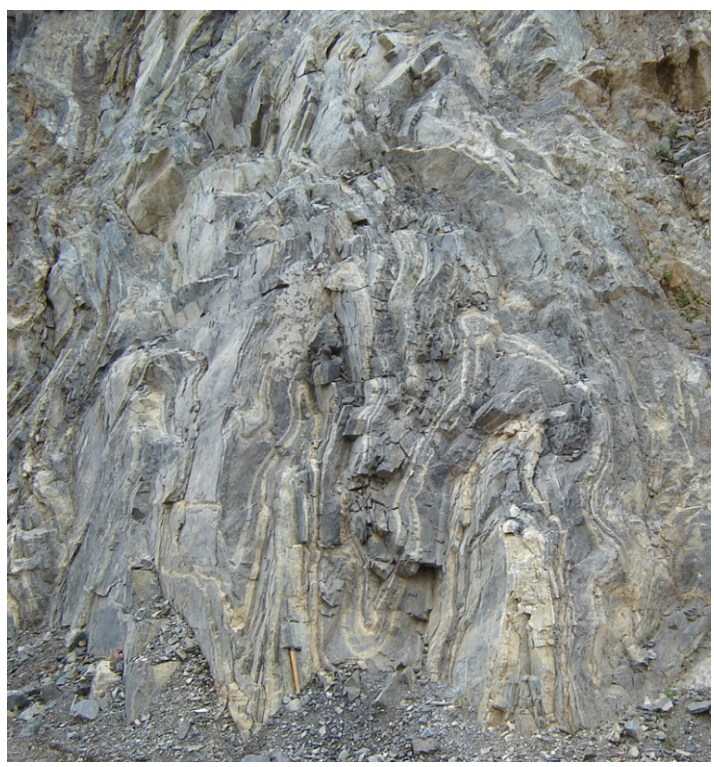

Figura 12. Dobras mesoscópicas de ápice espessado, exibindo padrão de interferência em laços

São Roque gerou dobras que podem ser enquadradas tanto na classificação baseada em isógonas de mergulho, como segundo outros critérios de classificação.

A classificação morfológica de dobras é, contudo, bastante limitada para estudos de evolução tectônica de uma região, sobretudo quando faltam dados de superposição estrutural. Sabe-se que idênticos estilos de dobramento podem se formar durante eventos deformacionais distintos. Seriam necessários estudos complementares para correlacionar as dobras estudadas com os eventos deformacionais descritos na literatura. Para se estabelecer durante qual evento deformacional determinada dobra se formou, é necessário conhecer os padrões de interferência. Algumas das imagens descritas e interpretadas no presente artigo revelam tais padrões, mas ainda não conhece com segurança a origem das dobras poli-harmônicas identificadas.

\section{Agradecimentos}

Os autores agradecem as bolsas de iniciação científica concedidas pelo programa PIBIC do Conselho Nacional de Desenvolvimento Científico e Tecnológico (CNPq), que viabilizaram a realização da pesquisa, e à empresa Votorantim Cimentos que gentilmente recebeu a equipe nos trabalhos de campo para coleta de dados; agradecem ainda aos geólogos Roberto Nakamura e Regiane Velozo, da Votorantim Cimentos, pelo apoio nos trabalhos de campo, e ao Sr. Ricardo Orlando pelas sugestões para edição das imagens. 


\section{Referências Bibliográficas}

Almeida F.F.M.de. 1969. Diferenciação Tectônica da Plataforma Brasileira. In: SBG, Congr. Bras. Geol., 23, Salvador, 1969. Anais..., Salvador, p.29-46.

Almeida F.F.M., Hasui Y., Ponçano W.L., Dantas A.S.L., Carneiro C.D.R., Melo M.S.de, Bistrichi C.A. 1981. Mapa Geológico do Estado de São Paulo, Esc. 1:500.000. São Paulo, IPT. v.1. (IPT, Monogr. 6, Nota Expl.).

Arthaud M.H. 1998. Elementos de Geologia Estrutural. Fortaleza. 116p.

Bergmann M. 1988. Caracterização Estratigráfica e Estrutural da Seqüência Vulcano-Sedimentar do Grupo São Roque - na região de Pirapora do Bom Jesus - Estado de São Paulo. São Paulo, Inst. Geoc., Univ. São Paulo. 164p. (Dissert. Mestrado).

Bianchini A.R., Carneiro C.D.R. 2007. Dobras e estilos de dobramentos em rochas carbonáticas na Mina de Salto de Pirapora da Cia. de Cimento Votorantim, Votorantim - SP. Campinas, IG-Unicamp. 19p. (Rel. Cient. Final).

Bistrichi C.A., Carneiro C.D.R., Dantas A.S.L., Ponçano W.L., Campanha G.A.C., Nagata N., Almeida M.A., Stein D.P., Melo M.S.de, Cremonini O.A., Hasui Y., Almeida F.F.M. 1981. Mapa Geológico do Estado de São Paulo, Esc. 1:500.000. São Paulo, IPT. v.2. (IPT, Monogr. 6, Mapa).

Carneiro C.D.R. 1983. Análise estrutural do Grupo São Roque na faixa entre o Pico do Jaraguá e a Serra dos Cristais, SP. São Paulo: Inst. Geoc., Univ. São Paulo, 155p. (Tese dout.).

Carneiro C.D.R., Lima M.O. de. 1989. Análise de foliações em áreas dobradas. São Paulo: IPT/Pró-Minério. 38p. (IPT, Publ. 1753)

Carneiro C.D.R., Rodrigues E.P., Coutinho J.M.V. 1984. Microestruturas e relações metamorfismo-deformação do Grupo São Roque na faixa entre o Pico do Jaraguá e a Serra dos Cristais, SP. Rev. Bras. Geoc., 14(2):98-110.

Carneiro C.D.R., Hasui Y., Nagata N., Lima M.O. de. 1985. Padrões de superposição de estruturas do Grupo São Roque na faixa Jaraguá-Cristais (SP). Rev. Bras. Geoc., 15(2):116-130.

Coutinho J.M.V. 1972. Petrologia do Pré-Cambriano em São Paulo e arredores. São Paulo, Bol. IG., 3: $160 \mathrm{p}$.

Coutinho J.M.V., Rodrigues E.P., Suemitsu A., Juliani C., Beljavskis P., Perosa P.T.Y. 1982. Geologia e Petrologia da seqüência vulcano-sedimentar do Grpo São Roque na Serra de Itaberaba, SP. In. Congr. Bras.Geol., 32, Salvador, 1982. Anais... Salvador, SBG. v. 2, p. 624-640.

Dantas E.L., Hackspacher P.C., Fetter A.H., Sato K., Pimental M.M., Godoy A.M. 2000. Sm/Nd isotope systematics related to Proterozoic evolution of the Central Ribeira Belt. São Paulo: Rev. Bras.
Geoc., 30(1): 140-143.

Godoy A.M., Hackspacher P.C., Oliveira M.P.F. 1996. Geologia da Região de Sorocaba, SP. Rio Claro, Geociências, 15(n.esp): 89-110.

Hackspacher P.C., Godoy A.M., Oliveira M.A.F. 1991. Tectônica transcorrente e de cavalgamento do sistema de cisalhamento do Sudeste Brasileiro. In: Simp. Nac. Est. Tectônicos, 3, Rio Claro, 1991. Boletim..., Rio Claro, SBG. v. 1, p. 223-230.

Hackspacher P.C., Godoy A.M., Oliveira M.A.F. 1993. Evolução crustal do Bloco São Roque na Região Sudeste do Estado de São Paulo. Rev. Bras. Geoc. 23(3):160-264.

Hasui Y. 1973. Tectônica das Folhas São Roque e Pilar do Sul. São Paulo, 190p. (Tese de Livre Docência IG/USP).

Hasui Y. 1975a. Evolução Polifásica do Precambriano a oeste de São Paulo. São Paulo, Bol. IG, 6:95-108.

Hasui Y. 1975b. Geologia da Folha São Roque. São Paulo, Bol. IG, 6:157-183.

Hasui Y., Carneiro C.D.R., Giancursi F.D. 1976. Condicionamento tectônico da Bacia Sedimentar de São Paulo. In: Congresso Brasileiro de Geologia, 29, Ouro Preto, 1976. Anais...Ouro Preto, SBG. 4: 257-268.

Hasui Y., Sadowski G.R., Carneiro C.D.R. 1976a. Considerações sobre a estratigrafia do Pré-Cambriano na região de São Paulo. Bol. IG., 7:107-112.

Hasui Y., Sadowski, G.R. 1976b. Evolução Geológica do Precambriano na Região Sudeste do Estado de São Paulo. Rev. Bras. Geoc. 6:182-200, São Paulo.

Hasui Y., Penalva F., Hennies W.T. 1969. Geologia do Grupo São Roque. In: SBG, Congr. Bras. Geol., 23, Salvador, 1969. Anais... Salvador, SBG. v. 1, p. 101-134.

Hennies, W.T., Hasui, Y., Penalva, F. 1967. O falhamento transcorrente de Taxaquara. In: SBG, Congr. Bras. Geol., 21, Curitiba, 1967. Anais... Curitiba, SBG. v. 1, p. 159-168.

Henrique-Pinto R. Janasi V.A., Simonetti A., Tassinari C.C.G, Heaman L.M.2012. Paleoproterozoic source contributions to the São Roque Group sedimentation: LA-MC-ICPMS U-Pb dating and $\mathrm{Sm}-\mathrm{Nd}$ systematics of clasts from metaconglomerates of the Boturuna Formation. Geol. USP, Sér. cient. [online], 12(3):21-32. URL: http://ppegeo.igc.usp.br/scielo.php?script $=$ sci pdf\&pid $=$ S1519-874X2012000300003\&lng $=\overline{p t}$ $\& n r m=i s o \& t \operatorname{lng}=e n$. Acesso 10.08.2014.

Hobbs B.E., Means W.D., Williams P.F. 1976. An outline of structural geology. New York: John Wiley. 571p.

Juliani C., Beljavskis P., Schorscher H.D. 1986. Petrogênese do vulcanismo e aspectos associados: Grupo Serra do Itaberaba na região de São Roque, SP. In: SBG, Congr. Bras. Geol., 34, Goiânia, 1986. Anais... Goiânia, SBG. v. 2, p. 730-747.

Juliani C., Hackspaker P., Dantas E.L., Fetter A.H. 
2000. The Mesoproterozoic volcano-sedimentary Serra do Itaberaba Group of the central Ribeira Belt, São Paulo, Brasil: implications for the age of the overlying São Roque Group. Rev. Bras. Geoc. 30: 82-86.

Loczy L., Ladeira E. A. 1976. Geologia Estrutural e Introdução à Geotectônica.São Paulo: Ed. Blücher / Rio de Janeiro: CNPq. 528p.

Moraes Rego L.F. 1930. Estados de São Paulo e Paraná. Rio de Janeiro: Serviço de Fomento à Produção Mineral, 83 p. (SFPM, Rel. Anual Diretor, 1929).

Nakamura R.T. 1995. Relatório de Reavaliação de Reservas DNPM 000.557/45 Decr. Lavra 34.102/53. Retificado pela Port. Lavra 1.181 de 23/08/82, DOU de 27/08/82. Votorantim, Cia. Cimento Votorantim. 19p. (Geól. Resp: Roberto T. Nakamura).

Ragan D.M. 1973. Structural Geology, an introduction to geometrical techniques. 2 ed. New York: John Wiley. $208 \mathrm{p}$.

Ramsay J.G. 1967. Folding and fracturing of rocks. New York, McGraw-Hill. 567p.

Ramsay J.G., Huber, M.I. 1987. The techniques of Modern Structural Geology. London: Academic Press, p. 308-700. (v. 2: Folds and Fractures).

Santoro E. 1986. Organização estrutural do Grupo São
Roque na Folha Cabreúva, SP. In: SBG, Congr. Bras. Geol., 34, Goiânia, 1986. Anais... Goiânia, SBG. v. 2, p. 891-904.

Silva P.C.F.da. 1997. Ambientes de sedimentação e tectônica do Grupo São Roque na região entre Pilar do Sul e Votorantim, SP. São Paulo, Inst. Geoc., Univ. São Paulo. 127p. (Dissert. Mestr.).

Silva P.C.F.da. 2004. Litofácies e prováveis ambientes de sedimentação do Grupo São Roque na região de Votorantim e Salto de Pirapora, SP. São Paulo, Rev. Inst. Geol. 25(1/2):29-48.

Twiss R.J., Moores E.M. 1992. Structural Geology. New York: W.H. Freeman and Co. 532 p.

Van Der Pluijm B.A., Marshak S. 2004. Earth Structure: An Introduction to Structural Geology and Tectonics. New York, W.W. Norton.

Van Schmus W.R., Tassinari C.C.G., Cordani U.G. 1986. Estudo Geocronológico da Parte Inferior do Grupo São Roque. In: Congr. Bras. Geol, 34, Goiânia, 1986. Anais..., Goiânia, SBG. 3v, p. 1399-1406. 